UCRL-ID-126996 Rev 2

\title{
National Ignition Facility SubSystem Design Requirements Optics Assembly Building (OAB)
}

SSDR 1.2.2.3

P. Kempel

August 22, 1996

This is an informal report intended primarily for internal or limited external distribution. The opinions and conclusions atated are those of the author and may or may not be those of the Laboratory.

Work performed under the auopices of the U.S. Department of Energy by the Lwrence Livermore National Laboratory under Contract W-7405-Eng-48. 


\section{DISCLAIMER}

This document was prepared as an account of work sponsored by an agency of the United States Government. Neither the United States Government nor the University of California nor any of their employees, makes any warranty, express or implied, or assumes any legal liability or responsibility for the accuracy, completeness, or usefulness of any information, apparatus, product, or process disclosed, or represents that its use would not infringe privately owned rights. Reference herein to any specific commercial product, process, or service by trade name, trademark, manufacturer, or otherwise, does not necessarily constitute or imply its endorsement, recommendation, or favoring by the United States Government or the University of California. The views and opinions of authors expressed herein do not necessarily state or reflect those of the United States Government or the University of California, and shall not be used for advertising or product endorsement purposes.

This report has been reproduced directly from the best available copy.

Available to DOE and DOE contractors from the Office of Scientific and Technical Information

P.O. Box 62, Oak Ridge, TN 37831

Prices available from (615) 576-8401, FTS 626-8401

Available to the public from the

National Technical Information Service

U.S. Department of Commerce

5285 Port Royal Rd.,

Springfield, VA 22161 


\section{National Ignition Facility}

\section{Subsystem Design Requirements}

\section{Optics Assembly Building (OAB) \\ SSDR 1.2.2.3}

Revision 2

August 22, 1996

Prepared By:

P. R. Kempel, Deputy Mgr, Conventional Facilities

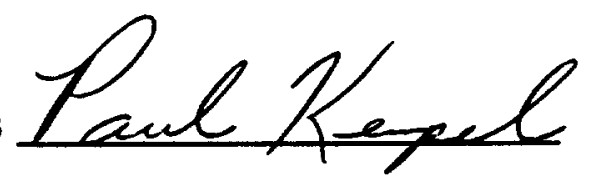

Date: $9-3-96$

J. Hands, Manager, Conventional Facilities

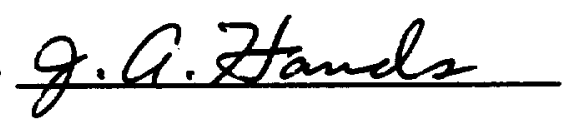

Date: $9-3-96$

Engineering Approval:

S. Kumpan, NIF Project Engineer S.A.K pan Approval Date: $04 \operatorname{Sep} 96$ 


\section{Contents}

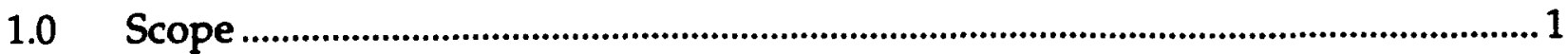

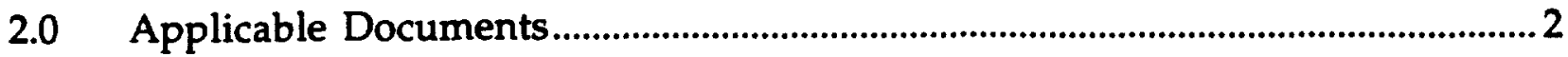

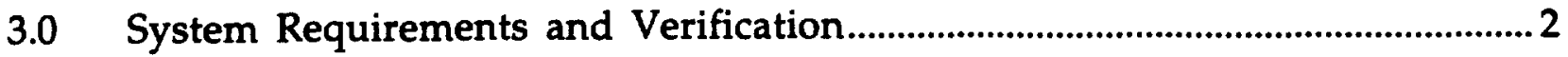

3.1 System Definition ............................................................................................. 2

3.1.1 System Description............................................................................ 2

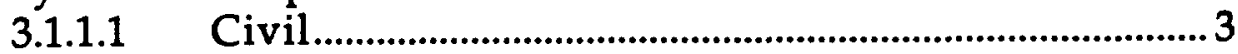

3.1.1.2 Structural.......................................................................... 3

3.1.1.3 Architectural...................................................................... 4

3.1.1.4 Heating, Ventilating, and Air Conditioning................6

3.1.1.5 Plumbing............................................................................. 8

3.1.1.6 Fire Protection................................................................... 8

3.1.1.7 Material Handling................................................................9

3.1.1.8 Mechanical Process Piping................................................. 9

3.1.1.9 Electrical and Industrial Electronics ............................. 10

3.2 System Characteristics and Verification........................................................11

3.2.1 Performance and Physical Characteristics........................................ 11

3.2.1.1 Civil .................................................................................. 11

3.2.1.2 Structural.................................................................. 11

3.2.1.3 Architectural..................................................................... 12

3.2.1.3.1 Functional Space Requirements.............13

3.2.1.3.2 Access and Egress .......................................... 13

3.2.1.3.3 Building Interior \& Exterior Finishes.. 13

3.2.1.3.4 Miscellaneous Metals................................. 15

3.2.1.3.5 Wood and Plastic .......................................... 15

3.2.1.3.6 Thermal and Moisture Control..............15

3.2.1.3.7 Doors and Windows .................................. 15

3.2.1.3.8 Specialties ........................................................16

3.2.1.3.9 Miscellaneous Special Equipment.........16

3.2.1.4 Heating, Ventilating, and Air Conditioning............. 16

3.2.1.4.1 Outdoor Design Conditions...................... 17

3.2.1.4.2 Indoor Design Conditions......................... 17

3.2.1.4.3 Ventilation..................................................... 17

3.2.1.4.4 Filtration..................................................... 17

3.2.1.4.5 Pressurization................................................. 19

3.2.1.4.6 Noise and Vibration Control .................. 19

3.2.1.4.7 Seismic Equipment Anchoring .............. 19

3.2.1.4.8 HVAC Controls...........................................20

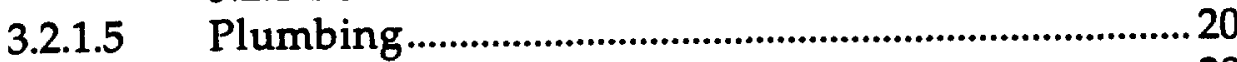

3.2.1.5.1 Potable Water................................................ 20

3.2.1.5.2 Sanitary Waste................................................. 20 
3.2.1.5.3 Stormwater Drains ....................................20

3.2.1.6 Fire Protection................................................................. 21

3.2.1.7 Material Handling............................................................. 21

3.2.1.8 Mechanical Process Piping Systems............................... 22

3.2.1.8.1 Deionized Water....................................... 22

3.2.1.8.2 Compressed Air.............................................. 22

3.2.1.8.3 Nitrogen......................................................... 22

3.2.1.8.4 Vacuum Cleaning.......................................2 23

3.2.1.9 Electrical and Industrial Electronics ............................23

3.2.1.9.1 Normal Power Distribution ..................... 23

3.2.1.9.2 Lighting........................................................... 24

3.2.1.9.3 Grounding................................................... 24

3.2.1.9.4 Air Ionozation...........................................25

3.2.1.9.5 Industrial Electronics .................................25

3.2.1.9.5.1 Telecommunications .......... 25

3.2.1.9.5.2 Fire Detection and Alarm.. 25

3.2.1.9.5.3 Evacuation Voice Alarm... 25

3.2.1.9.5.4 Oxygen Deficiency and Nitrogen Monitoring ..........26

3.2.1.10 Verification of OAB Designs..........................................26

3.3 Design and Construction ...........................................................................26

3.3.1 Civil.............................................................................................. 26

3.3.2 Structural............................................................................................... 26

3.3.3 Architectural....................................................................................... 26

3.3.4 Heating, Ventilating, and Air Conditioning.................................26

3.3.5 Plumbing......................................................................................... 26

3.3.6 Fire Protection................................................................................... 27

3.3.7 Material Handling........................................................................... 27

3.3.8 Mechanical Process Piping.................................................................2

3.3.9 Electrical and Industrial Electronics ............................................. 27

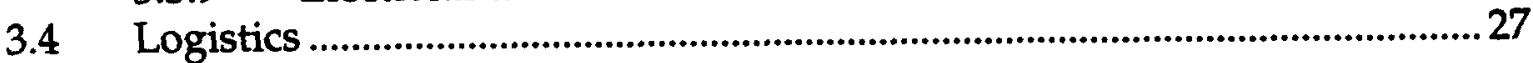

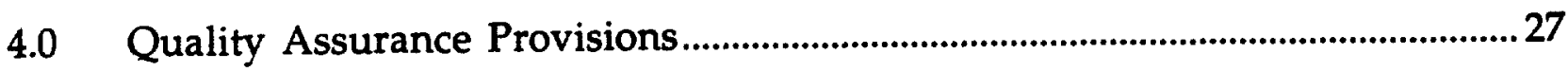

4.1 Q-Levels (Quality Assurance Levels) .......................................................27

4.2 Quality Requirements................................................................................. 28

4.3 Quality Assurance Measures ........................................................................28

4.3.1 OAB Subsystems........................................................................... 28

4.3.2 Subsystem Design Verification....................................................... 28

4.3.3 Subsystem Construction Verification.............................................28

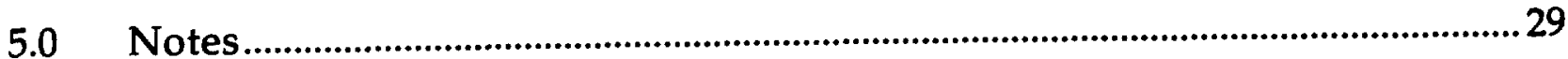

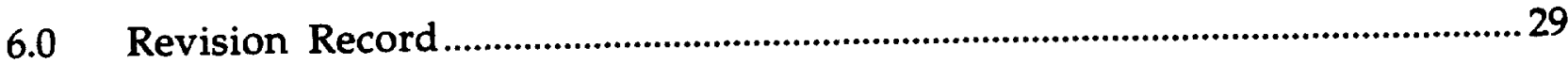




\section{List of Figures and Tables}

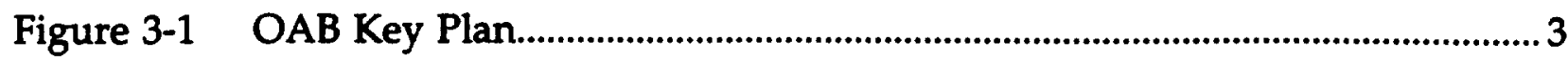

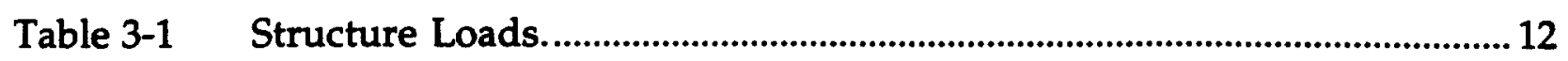

Table 3-2 Space Requirements........................................................................................... 14

Table 3-3 Indoor HVAC Design Conditions....................................................................... 18 


\subsection{Scope}

This Subsystem Design Requirement (SSDR) document establishes the performance, design, and verification requirements for the conventional building systems and subsystems of the Optics Assembly Building (OAB). These building system requirements are associated with housing and supporting the operational flow of personnel and materials throughout the $\mathrm{OAB}$ for preparing and repairing optical and mechanical components used in the National Ignition Facility (NIF) Laser and Target Building (LTAB).

This SSDR addresses the following subsystems associated with the OAB:

- Structural systems for the building spaces and operational-support equipment and building-support equipment.

- Architectural building features associated with housing the space, operational cleanliness, and functional operation of the facility.

- Heating, Ventilating, and Air Conditioning (HVAC) systems for maintaining a clean and thermally stable ambient environment within the facility.

- Plumbing systems that provide potable water and sanitary facilities for the occupants and stormwater drainage for transporting rainwater.

- Fire Protection systems that guard against fire damage to the facility and its contents.

- Material handling equipment for transferring optical assemblies and other materials within building areas and to the LTAB.

- Mechanical process piping systems for liquids and gases that provide cooling, cleaning, and other service to optical and mechanical components.

- Electrical power and grounding systems that provide service to the building and equipment, including lighting distribution and communications systems for the facilities.

- Instrumentation and control systems that ensure the safe operation of conventional facilities systems, such as those listed above.

Generic design criteria, such as siting data, seismic requirements, utility availability, and other information that contributes to the OAB design, are not addressed in this document. Rather, such information is provided in SDR 001, Conventional Facilities System Design Requirements, and SSDR 1.2.1, NIF Site Improvements Subsystem Design Requirements. Similarly, detailed requirements for building subsystems (such as specific sizes, locations, or capacities) that are not addressed in this document are identified in detail-level NIF Project Interface Control Documents (ICDs). 


\subsection{Applicable Documents}

Consensus codes and standards, and reference documents applicable to OAB subsystems are listed at the beginning of each discipline heading in Section 3.2.

\subsection{System Requirements and Verification}

\subsection{System Definition}

\subsubsection{System Description}

The OAB subsystem consists of an integrated arrangement of building spaces, structures, and utility subsystems that sustain NIF optical and mechanical component assembly and repair operations. The $O A B$ has a significant role in fulfilling the NIF mission, supporting LTAB operations in these ways:

- Prior to and during LTAB operations, new optical and mechanical components are delivered from outside sources to the $O A B$ for cleaning, assembly, alignment, and testing. When completed, these assemblies are either stored temporarily or transported directly to the LTAB for installation.

- During experimental operations at the LTAB, damaged optical assemblies are transported back to the $O A B$ for inspection and disassembly for repair or replacement, and the cycle is repeated.

All components arrive at the loading area and undergo receiving inspection in an enclosed area. Adjacent to this loading/unloading space, separate clean rooms are provided in the main part of the building for preparation and transfer of optical and mechanical components of line replaceable units (LRUs). The mechanical components undergo additional cleaning and partial assembly in an incrementally clean space. Final assembly of these components and alignment and testing of the assemblies are performed in another specially outfitted clean-room space. A special transfer cell and mechanical lift are provided for moving completed assemblies out of the $\mathrm{OAB}$ assembly area and onto a transporter for delivery through the corridor link to the LTAB. The basic arrangement of these functional spaces of the OAB is illustrated in Figure 3-1, OAB Key Plan.

The subsystems that comprise the conventional facilities of the $\mathrm{OAB}$ are the building structures, utility systems, and building components that serve the facility and operational hardware needs. These $O A B$ subsystems are described in the paragraphs that follow. 


\subsubsection{Civil}

Civil discipline is not applicable within the OAB. For topographic, subsurface, and other siting data, generic design criteria, utility locations, and other information that contributes to the OAB design, refer to SDR 001, Convention Facilities System Design Requirements, and SSDR 1.2.1, Site Improvements Subsystem Design Requirements.

Figure 3-1, OAB Key Plan

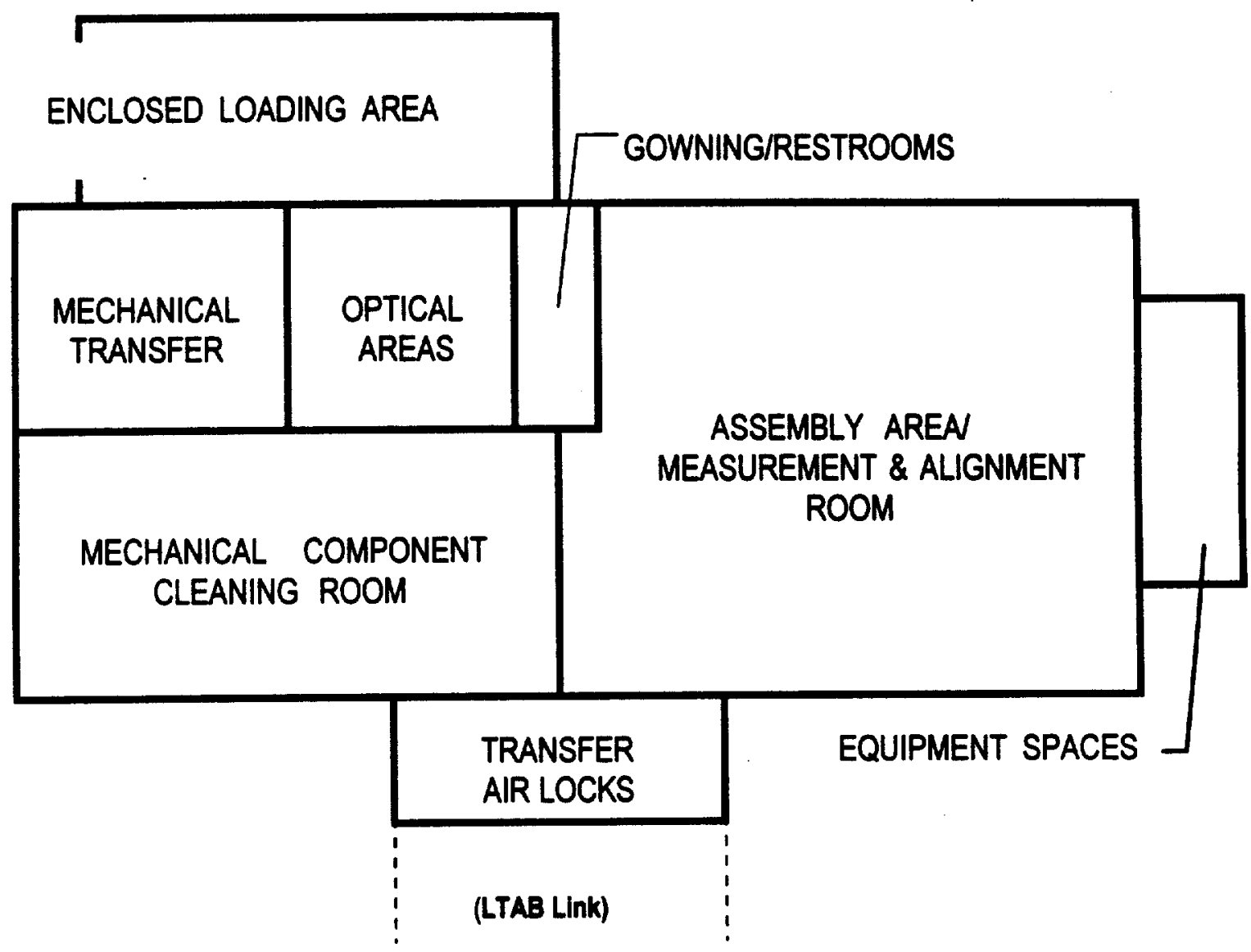

\subsubsection{Structural}

The building structural system consists of reinforced-concrete foundations and floor slabs and a steel-framed superstructure.

Concrete slabs, including those beneath raised floors (see Section 3.1.1.3), are separated from structural foundations to isolate vibrations and prevent their trans- 
mission through the structure or the raised floor system to sensitive alignment equipment above. Process equipment associated with the operations performed in each of the clean rooms is mounted on isolated reinforced-concrete foundations in the earth below the raised-floor space, i.e., equipment mountings extend through the raised-floor space. The raised-floor space forms return-air plenums beneath Class 100 and 1000 clean rooms.

Wherever large rotating equipment that could create undesirable noise or vibration is needed, it is mounted on reinforced-concrete foundation pads outside the main $O A B$ footprint to ensure vibration isolation.

The structural system is more fully described in construction drawings and specifications, which interpret the structural designs, provide information for bidding purposes, and give directions for concrete construction, steel erection, inspection, and testing. The following configuration control drawings outline the scope of the OAB:

\section{Configuration Control Drawings}

Drawing Number

Title

TBD

TBD

\subsubsection{Architectural}

The $O A B$ is a facility consisting of four major operating spaces with special cleanroom features to accommodate sensitive and precise functions associated with preparing NIF mechanical and optical components for use in the LTAB. These spaces have 14-ft-high suspended ceilings, with ducts and air-supply plenums above, and 4-ft raised floors forming return-air plenums below. Airlocks are provided between all adjacent rooms. Each clean-room space has special temperature and humidity controls for its environment, and at least one false wall that forms a return-air duct from the raised-floor space below to the mechanical loft space above the suspended ceilings.

The approximate overall dimensions of the main portion of the building containing these spaces are as follows: $100 \mathrm{ft}$ wide by $186 \mathrm{ft}$ long by $35 \mathrm{ft}$ high above the raisedfloor level. This entire area has a 14.5-ft-high "mechanical loft" with an opengrating floor and 4-ft-high duct spaces between the loft floor and the suspended ceiling. The mechanical loft is divided into separate spaces forming supply-air plenums that match the clean-room spaces below.

One-story-high spaces are also provided in the $O A B$ for support functions and equipment, including an enclosed loading area for receiving and inspecting individual components; a transfer area for moving assembled components through specially equipped airlocks to the corridor link to the LTAB; rest rooms and gowning areas for putting on protective clothing prior to entering the clean-room spaces; 
equipment rooms to house operations support equipment, such as a deionized water generator, and building mechanical and electrical equipment; and a covered outdoor viewing area for visitors to observe final assembly and alignment operations.

The $\mathrm{OAB}$ is connected to on-site utilities and gets heating and cooling media through underground piping from the NIF Service Equipment Building (SEB) nearby. There is also a 10,000 -gal deionized-water storage tank provided near the $\mathrm{OAB}$ (see Section 3.1.1.8).

The OAB contains approximately $26,000 \mathrm{sq} \mathrm{ft}$, not including the mechanical loft space above the suspended ceilings, as follows:

Class 100 Clean Rooms:

- Assembly area/measurements and alignment room, gowning room (at Corridor Link to the LTAB), and (3) Airlocks.

- Office/computer room.

- Gowning room with lockers.

The assembly area has features (sealed ceiling and roof penetrations) to accommodate the future installation of an area hood and exhaust system for an operation using sol-gel.

Class 1000 Clean Rooms:

- Mechanical component cleaning room and (2) airlocks.

Class 10000 Clean Rooms:

- Mechanical component transfer area and airlock.

- Optical component transfer area and airlock.

The mechanical loft above these spaces is divided into separate air-supply plenums consistent with the clean rooms they serve.

Clean Zones (Class 100,000):

- Men's and women's toilets.

- Transfer facility (depressed area) to corridor link to the LTAB.

Airlocks:

Airlocks between spaces have the cleanliness classification of the cleaner adjacent space.

Support Areas (outside the main building footprint):

- Enclosed loading area.

- Mechanical, electrical, and communications equipment rooms.

- Visitors' viewing area (exterior). 
The OAB is located approximately $70 \mathrm{ft}$ from the east end of the LTAB and will link the 20-ft-long Transfer Area to the LTAB with a 50-ft-long corridor structure. Due to Uniform Building Code (UBC) occupancy classification F-1 for the OAB, and because of its proximity to the $L T A B$, the west wall of the $O A B$ has special fire-resistant features in its construction.

Paved pathways link the main entrances of the $O A B$ and $L T A B$, the OAB Viewing Area, and parking areas.

The architectural features of the $\mathrm{OAB}$ are more fully described in construction drawings and specifications, which interpret the space designs and features, provide information for bidding purposes, and give directions for construction, installation, inspection, and testing. The following general arrangement drawings outline the space of the OAB:

General Arrangement Drawings

Drawing Number

Title

TBD

TBD

\subsubsection{Heating, Ventilating, and Air Conditioning (HVAC)}

The OAB HVAC systems are designed to meet special and critical requirements for cleanliness, thermal stability, minimum vibration, and reliability during operation of the facility.

In general, tempered air is distributed to the clean-room spaces at low velocities through round ducts with sound traps and long-radius elbows to minimize noise and vibrations. The air is distributed through suspended ceiling panels to the room spaces, exhausted through the perforated raised-floor sytem to the return-air plenum spaces, then back up to the loft for filtration and recycling. Direct digital controls regulate all functons of the HVAC systems and annunciate malfunctions to the LLNL site central monitoring system. Rotating equipment is mounted with appropriate vibration isolation to the building structure and flexible connections to ductwork.

Hot-water and chilled-water supply to coils in $O A B$ air handling units is provided from boiler and chiller equipment located at the SEB, nearby on the NIF site, and routed underground to the OAB. This equipment and underground piping is addressed in SSDR 1.2.1, NIF Site Improvements. For the OAB, distribution piping to the coils is routed within the building to the mechanical loft where the coils are located and is configured to suppress hydraulic shock. 
The systems controlling the ambient environment of each of the OAB spaces are described in the paragraphs that follow. 
Assembly Area/Measurement and Aligniment Room, Office, and Airlocks-The HVAC system for these areas consists of a number of recirculating air-handling units located in the mechanical loft, maintaining a constant volume of air. Each air handling unit has a fan, cooling coil, sound traps, and high-efficiency particulate air (HEPA) filters. The HVAC system provides a Class 100 cleanliness environment for this space, including the main room, three airlocks, and the Office. An electronic air-ionization system is also provided for this space.

Make-up air to maintain the proper pressure and atmospheric conditions in the Assembly Area is provided by a large make-up air handling unit that serves all the clean-room spaces and is located in the mechanical loft. This unit consists of a fan, preheat and reheat coils, humidifier (steam generator), dehumidifier (cooling) coil, sound traps, and filters. Discharge air from this unit is ducted to each of the mechanical loft air-supply plenums.

Mechanical Component Cleaning Room \& Airlocks-The HVAC system for the Mechanical Cleaning Room consists of recirculating air-handling units located in the mechanical loft, maintaining a constant volume of air. Each air handling unit has a fan, cooling coil, sound traps, and HEPA filters. The HVAC system pro-vides a Class 1000 cleanliness environment for this room and two airlocks. Make-up air to maintain the proper pressure and environmental conditions in this room is also provided by the make-up air handling unit described above.

Mechanical and Optical Component Transfer Areas and Airlocks-The HVAC systems for these rooms each consist of a recirculating air-handling unit located in the mechanical loft, maintaining constant volumes of air to each space. Each air handling unit has a fan, cooling coil, sound traps, and HEPA filters. These HVAC systems provide Class 10,000 cleanliness environments for these rooms and airlocks to the loading dock area. Make-up air to maintain the proper pressure and environmental conditions is also provided by the make-up air handling unit described above..

Gowning Room and Airlock-The HVAC system for these spaces consists of a recirculating air-handling unit located in the mechanical loft, maintaining a constant volume of air. The unit has a fan, cooling coil, sound traps, and HEPA filters. This system provides a Class 100 cleanliness environment for the Gowning Room and airlock to the enclosed Loading Dock. Make-up air to maintain the proper pressure and environmental conditions in these spaces is also provided by the make-up air handling unit described above.

Transfer Area to Corridor Link to LTAB-The HVAC system for these spaces consists of a recirculating air-handling unit located in the mechanical loft, maintaining a constant volume of air. The unit has a fan, cooling coil, sound traps, and HEPA filters. This system provides a Class 100 cleanliness environment for the Gowning Room and equipment transfer airlock from the Mechanical Cleaning Room to the Corridor Link. Make-up air to maintain the proper pressure and envi- 
ronmental conditions in these spaces is also provided by the make-up air handling unit described above.

Loading Area-The HVAC system for the enclosed loading area consists of a dedicated air-handling unit including a supply fan, cooling coil, heating coil, and filters. The air handling unit circulates air through the space to maintain temperatures in the required range. There are no special cleanliness requirements for this system.

These systems are more fully described in the construction drawings and specifications, which interpret the HVAC and HVAC-Controls designs, provide information for bidding purposes, and give directions for fabrication, installation, inspection, testing, and balancing.

\subsubsection{Plumbing}

Plumbing systems for the OAB consist of domestic cold water (potable water), sanitary waste, and stormwater drains. The systems serving the building are described in the paragraphs below.

The domestic cold water system on site (underground) is approximately 100 psig and is reduced to $80 \mathrm{psi}$ at the building, then distributed in the building to serve lowflow fixture-unit requirements. In addition to sanitary fixtures, the system also serves a process water requirement (see Section 3.1.1.8).

The sanitary soil/waste and vent system provides the necessary sanitary effluent from the $O A B$ in accordance with local codes. The interior sanitary waste piping is routed and connected to the fixture units in the building. Traps with integral trap primers are provided in the piping system.

The stormwater drainage system consists of roof scuppers and downspouts, foundation drains, an area drain at the base of the loading dock ramp, and associated piping to convey the water away from the building. Piping is designed for the maximum design rainfall of $4 \mathrm{in} / \mathrm{hr}$ and is routed to the site storm drainage system in accordance with the local plumbing code.

These systems are more fully described in construction drawings and specifications, which interpret the plumbing designs, provide information for bidding purposes, and give directions for construction, installation, inspection, and testing.

\subsubsection{Fire Protection}

The $O A B$ fire suppression systems consist of automatic dry-pipe sprinklers, in all occupied and concealed spaces, and portable fire extinguishers. Sprinkler system designs and densities are based on NFPA Ordinary Hazard, Group 2 occupancy. 
Fire Protection water supply is provided by connection to the site water system loop. Service connections include backflow prevention, flow detector alarms, valve supervision, fire department connections, and inspector's test and drain valves. System risers are located inside the building. Fire detection and alarms are discussed in Section 3.1.1.9.

The sprinkler systems are more fully described in construction drawings and specifications, which interpret the fire protection and control system designs, provide information for bidding purposes, and give directions for construction, installation, inspection, and testing.

\subsubsection{Material Handling}

Two mechanical lift mechanisms are provided for transferring components and LRU assemblies through airlocks from the Mechanical Component Cleaning Room and the Assembly Area/Measurements and Alignment Room to the Corridor Link to the LTAB.

Reinforced-concrete foundations and anchorage (only) are provided for the future installation of robotic equipment and/or jib cranes in the following spaces:

- Optical Component Transfer Area (TBD).

- Mechanical Component Transfer Area (TBD).

- Mechanical Component Cleaning Room (TBD).

- Assembly Area/Measurements and Alignment Room (TBD).

These features are more fully described in construction drawings and specifications, which interpret the material handling equipment designs, provide information for bidding purposes, and give directions for construction, installation, inspection, and performance testing.

\subsubsection{Mechanical Process Piping}

The mechanical process piping systems for the OAB include the following:

- Process Water.

- Deionized Water.

- Compressed Air.

- Nitrogen.

- Housekeeping Vacuum Cleaning System.

Process water is provided for operations use by supply piping from the city-water supply system (see Section 3.1.1.5) to an isolation valve and backflow preventer at the deionizing equipment in the Mechanical Room. 
Deionized water (DIW) for component cleaning operations in the OAB is provided by deionization and polishing equipment in the Mechanical Equipment Room, an exterior 10,000-gal storage tank, and a collection and pumping system. Recirculating DIW piping is routed in the building to valved piping stubs for connection to cleaning stations at TBD locations.

Compressed air for instrumentation and operations use is supplied at 100 psi by compressors located on site at the SEB (see SSDR 1.2.1). Compressed air piping is routed in the $O A B$ to conventional-facilities instruments and equipment actuators. Compressed air piping is also routed in the building to valved piping stubs at TBD locations in the operations spaces for pneumatic tools.

Nitrogen for cleaning optical and other components of LRUs is supplied by a large dewar on site (see SDR 002). Nitrogen piping is routed underground to the OAB, and a piping distribution system to provided to valved piping stubs at TBD locations in the operations spaces of the building.

An industrial grade, housekeeping vacuum cleaning system is provided with outlets and hoses for general service in each clean-room space in the OAB. The motorized collection unit is located in the Mechanical Equipment Room, with suction piping distributed to valved fittings in the walls of the operations spaces.

Process vacuum at $25 \mathrm{~mm} \mathrm{Hg}$ is separately supplied by the NIF Project using portable, dedicated duplex vacuum pumps for each separate operation in the OAB. These pumps are not part of the OAB conventional facilities subsystems.

The mechanical process systems are more fully described in the construction drawings and specifications, which interpret the piping and equipment designs, provide information for bidding purposes, and give directions for construction, installation, inspection, flushing, and testing.

\subsubsection{Electrical and Industrial Electronics}

Electrical and electronics work for the $\mathrm{OAB}$ consists of a power-distribution system serving the building and operations equipment, lighting, communications, fire detection and alarms, evacuation voice/alarm, and grounding systems. Detailed description TBD after design is established.

These systems are more fully described in the construction drawings and specifications, which interpret the electrical distribution system designs, provide information for bidding purposes, and give directions for construction, installation, inspection, and testing. 


\subsection{System Characteristics and Verification}

Generic design criteria for NIF conventional facilities (design lifetime, performance class, reliability, seismic and wind criteria, quality assurance, etc.) are identified in NIF SSDR 1.2.1, Site Improvements and SDR001, Conventional Facilities System Design Requirements. The design of OAB subsystems addressed in this SSDR shall comply with the general criteria established in SSDR 1.2.1 and SDR001 in addition to those specifically identified in this section (Section 3.2).

\subsubsection{Performance and Physical Characteristics}

Certain quantitative and qualitative system or subsystem design attributes emerge from this or other SSDR(s) and may be identified in lower-level ICDs. In cases where the SSDR and ICD are silent in regard to essential subsystem design criteria, and unless otherwise specifically stated herein, DOE Order 6430.1A, General Design Criteria, dated $4 / 6 / 89$, is to be used for design guidance in meeting performance criteria established in this requirements document.

\subsubsection{Civil}

(Not applicable. Refer to SDR001, Conventional Facilities System Design Requirements, and SSDR 1.2.1, Site Improvements Subsystem Design Requirements, for topographic and subsurface data, siting information, utility locations, etc.)

\subsubsection{Structural}

Structural designs for the OAB shall be performed in accordance with the following standards:

- General: - International Council of Building Officials, UBC

- LLNL Special Requirements for Structural Design

- DOE Order 6430.1A, General Design Criteria

- DOE STD 1020-94, Natural Phenomena Hazards Design

- Design: - American Society of Civil Engineers, ANSI/ASCE 7-88,

- Code Requirements for Min. Design Loads for Buildings

- Concrete: American Concrete Institute, ANSI/ACI-318

- Steel: American Institute of Steel Construction, AISC Manual M011

Structure floor loading and other characteristics associated with operational requirements for OAB spaces are listed in Table 3-1. Generic design requirements for NIF buildings are addressed in SDR001 and SSDR 1.2.1. 
Table 3-1 - Structure Loads

\begin{tabular}{|c|c|c|c|c|}
\hline Building Area & $\begin{array}{l}\text { Floor } \\
\text { Live Load }\end{array}$ & Deflection & Vibration & Noise \\
\hline $\begin{array}{l}\text { Class 100 Clean-Room Spaces: } \\
\text { Ass'y/Meas/Alignm't Rm } \\
\text { Office/Computer Rm } \\
\text { Gowning Rooms }\end{array}$ & $\begin{array}{l}\text { (Notes } 1 \& 2) \\
350 \text { psf } \\
1400 \text { concent. } \\
100 \text { psf } \\
100 \text { psf }\end{array}$ & $\begin{array}{l}\text { TBD } \\
\text { TBD } \\
N / A\end{array}$ & $\begin{array}{l}<1 \times 10^{-8} \mathrm{~g}^{2} \mathrm{~Hz} \\
\text { from } 1-200 \mathrm{~Hz} \text {, } \\
(\text { Note } 3)\end{array}$ & (Note 4) \\
\hline $\begin{array}{l}\text { C1000 Clean-Room Spaces: } \\
\text { Mech Comp Cleaning Rm }\end{array}$ & $\begin{array}{l}\text { (Notes } 1 \& 2 \text { ) } \\
350 \text { psf } \\
1400 \text { concent. }\end{array}$ & TBD & (Note 3) & (Note 4) \\
\hline $\begin{array}{l}\text { C1 10,000 Clean-Room Spaces: } \\
\text { Mech Transfer Area } \\
\text { Optics Transfer Area }\end{array}$ & $\begin{array}{l}\text { (Note } 1) \\
350 \text { psf } \\
1400 \text { concent. } \\
350 \text { psf } \\
1400 \text { concent. }\end{array}$ & $\begin{array}{l}\text { TBD } \\
\text { TBD }\end{array}$ & (Note 3) & (Note 4) \\
\hline $\begin{array}{l}\text { Clean Zones (Class 100,000): } \\
\text { Toilet Rooms } \\
\text { Transfer facility to corr. link }\end{array}$ & $\begin{array}{l}100 \text { psf } \\
350 \text { psf } \\
1400 \text { concent. }\end{array}$ & $\begin{array}{l}\mathbf{T B D} \\
\mathbf{N} / \mathrm{A}\end{array}$ & (Note 3) & (Note 4) \\
\hline $\begin{array}{l}\text { Support Area Spaces: } \\
\text { Loading area } \\
\text { Equipment Rooms } \\
\text { Mechanical Loft }\end{array}$ & $\begin{array}{l}125 \text { psf } \\
3000 \text { concent. } \\
125 \text { psf } \\
3000 \text { concent. } \\
\text { TBD psf } \\
\text { TBD concent. }\end{array}$ & $\begin{array}{l}\text { TBD } \\
\text { TBD } \\
\text { TBD }\end{array}$ & (Note 3) & (Note 4) \\
\hline
\end{tabular}

\section{Notes:}

1) Airlocks shall be designed to the requirements of the most stringent adjacent space.

2) Raised floor in these areas shall have sufficient capacity to support 750-lb rolling wheel loads.

3) Building structures shall incorporate design features to reduce the transmission of vibrations to mechanical and optical components and LRUs in the Measurement and Alignment Room.

4) Building structures shall incorporate design features to reduce noise transmission to mechanical and optical components and LRUs in the Measurement and Alignment Room.

\subsubsection{Architectural}

Architectural designs for the OAB shall be performed in accordance with the following standards:

- International Council of Building Officials, UBC, F-1 Occupancy, Factory and Industrial.

- National Fire Protection Assn, NFPA 101, Life Safety Code, Industrial Occupancy. 
- Uniform Federal Accessibility Standard FED STD 975.

- Federal Standard 209E, Clean Room Work Station Requirements, Controlled Environment.

- Occupational Safety and Health Standards, 29 CFR 1910.

\subsection{Functional Space Requirements}

Functional space requirements and other characteristics associated with operational requirements are listed in Table 3-2. Cleanliness classifications are those characterized in Federal Standard 209E. Construction materials shall meet UBC requirements specified for Type II-N. Toilet facilities shall be provided according to the Uniform Plumbing Code for 22 people working in the facility.

Occupancy Classification F-1 is due to the potential presence of sol-gel for (future) coating of optics in the Assembly Area/Measurement and Alignment Room. This requirement affects the design and construction of the west building wall nearest the LTAB. Additionally, sealed penetrations shall be provided in the ceiling and roof to facilitate the future installation of an exhaust duct (see Section 3.2.1.4.3) and to support space and capacity for the hood and exhaust fan.

\subsection{Access and Egress}

Building spaces, corridors, stairways, exits, and exit paths shall meet the requirements for the construction and occupancy classifications established in the referenced code documents, including requirements for handicapped access to the viewing window to the Assembly Area/Measurement and Alignment Room and to the main personnel entrance to the facility.

In order to maintain the differential atmospheric pressures required in $\mathrm{OAB}$ spaces, access to the building from the exterior or from the adjacent LTAB shall be through airlock spaces. Access between internal OAB spaces that have differing ambient pressures or cleanliness classifications shall also be through airlock spaces.

An access ladder (with safety cage) shall be provided for roof access. Personnel roof protection shall be provided around the perimeter of the roof.

\subsection{Building Interior and Exterior Finishes}

Interior building spaces designated as "clean rooms" or "clean zones" shall have smooth, durable, sealed surface finishes, such as epoxy coatings that do not chalk, slough, or otherwise give off particles or gases, and shall be compatible with the environment of spaces with cleanliness classifications listed in Table 3-2. Airlocks shall be finished in the same manner as the more stringent adjacent space. 
Table 3-2 - Space Requirements

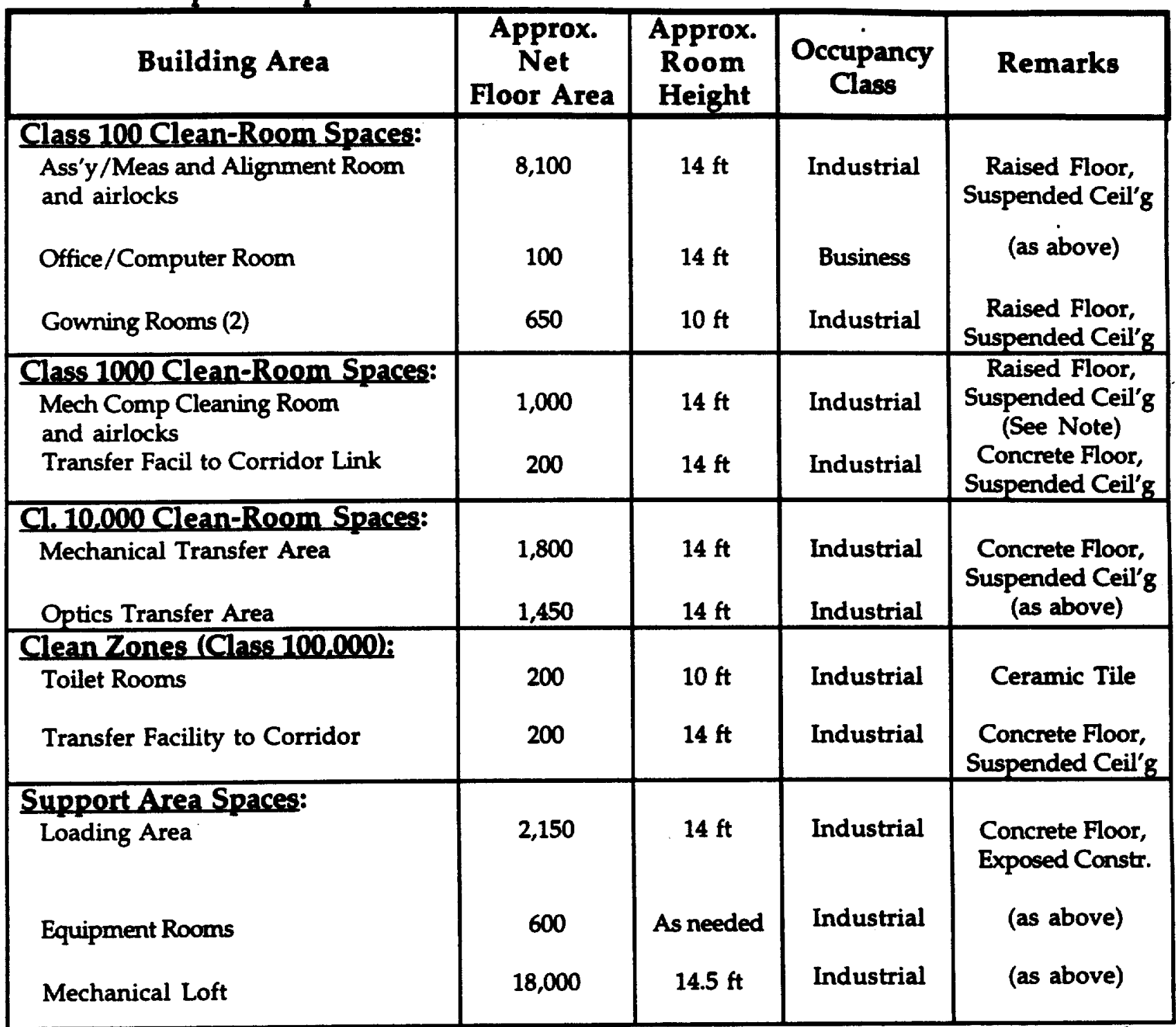

Note: Concrete floor slab beneath raised floor shall be sloped to floor drain in this area.

The Class 100 and 1000 clean-room operations areas shall have a braced, raised-floor system compatible with structural loading (Table 3-1), air-handling, and cleanliness requirements, as well as a suspended ceiling system compatible with the air-handling system and cleanliness requirements.

Interior loading area and equipment spaces shall have exposed construction, with sealed concrete floors and painted finishes to expedite good industrial housekeeping.

Exterior building panels shall be organic-coated metal siding, coordinated with the LTAB exterior. Exposed structural steel shall be finished with a suitable durable 
coating system. Canopies at building entrances, over the loading dock, stairs, and viewing window shall be similarly coated to match adjacent surfaces.

\subsection{Miscellaneous Metals}

Stairs, handrails, grating, ladders etc., shall be galvanized steel, finished with suitable durable coatings. Stairs shall have non-skid, concrete-filled treads. Roll-up doors, hollow metal doors, and windows shall be finished with a suitable, compatible, durable coating system.

\subsection{Wood and Plastic}

Countertops, shelving, laminates, and similar finishes used in clean-room spaces shall be non-outgassing materials.

\subsection{Thermal and Moisture Control}

Insulation and vapor barriers shall be provided to create a tight building envelope that ensures the thermal stability of the interior space environment.

A roofing membrane and all necessary flashing shall be provided to weatherproof the building and ensure the environmental stability of the interior spaces.

Concrete foundations surrounding depressed slab areas (beneath raised floors) shall be waterproofed and shall have a perimeter drainage system (see Section 3.2.1.5.3).

Concrete slabs and equipment foundations separated from the building foundation to attenuate vibration shall have the gaps filled and sealed with suitable material that does not transfer vibration.

\subsection{Doors and Windows}

Insulated hollow-metal exterior and interior personnel doors and frames shall be provided between all spaces. Double doors shall be provided for openings where inprocess equipment components must pass through. Door glazing shall be polishedwire-reinforced. Minimum door sizes TBD. Hardware, locks, and hinges meeting federal hardware specifications shall be provided for all doors. Locksets shall have cylinders to accept LLNL security cores TBD.

A (size TBD) power-operated, overhead, roll-up door shall be provided for the enclosed loading area.

Windows with hollow-metal frames and fixed, polished-wire-reinforced glazing shall be provided between the Office/Computer Room and Assembly Area and in the exterior wall at the visitors' viewing window to the Assembly Area. Exterior windows shall have thermally insulated glazing. 


\subsection{Specialties}

Suitable toilet partitions, accessories, fire extinguisher cabinets, signs, etc., shall be provided throughout, furnishing a complete facility, ready for occupancy.

\subsection{Miscellaneous Special Equipment}

All rotating and/or reciprocating equipment within the main OAB structure shall be mounted with suitable vibration isolation devices to prevent the transfer to operations spaces of vibrations exceeding those allowable in Table 3-1 (above).

Suitable barriers shall be provided at the overhead door to the loading area to protect the door opening from damage by vehicles.

Unless otherwise provided by parapet design, suitable railings or other barriers shall be provided for fall protection from the building roof.

\subsubsection{Heating, Ventilating, and Air Conditioning}

HVAC designs for the OAB shall be performed in accordance with the following standards:

- American Society of Heating, Refrigeration, and Air Conditioning Engineers, ASHRAE Guide, and associated standards.

- Airborne Particulate Cleanliness Classes, FED STD 209E.

- ACGIH Industrial Ventilation Manual.

- AMCA - Air Movement and Control Association.

- ANSI/AIHA Standard Z9.5, Laboratory Ventilation.

- ANSI/ASME N510 Nuclear Air-Cleaning Handbook.

- ARI - Air-Conditioning and Refrigeration Institute.

- DOE Order 5400.5, Radiation Protection of the Public and Environment.

- Energy Conservation standards, 10CFR 435 \& 436.

- Factory Mutual Standards.

- NEC - National Electrical Code.

- National Fire Protection Assn Standards.

- LLNL Facilities Standards.

- LLNL Health and Safety Manual.

- SMACNA - Sheet Metal and Air-Conditioning Contractors Nat'l Ass'n.

- Uniform Building Code, ICBO.

- Uniform Mechanical Code, ICBO.

- Uniform Plumbing Code, ICBO. 
An HVAC system design that optimizes energy consumption and building life-cycle costs shall be provided for the $\mathrm{OAB}$ as a consequence of a comprehensive analysis of the building's energy conservation aspects. 


\subsection{Outdoor Design Conditions}

Outdoor conditions for the LLNL preferred site shall be those listed for $1 \%$ ASHRAE Weather Data for Livermore, CA. The following outdoor environmental design conditions apply:

- Location:

- Latitude/Longitude:

- Elevation:

- Summer:

- Mean Daily Temp Range:

- Winter:

- Heating Degree Days:
Livermore, CA. $37.700 \mathrm{~N}, 122 \infty \mathrm{W}$. $490 \mathrm{ft}$ above MSL. $100 \circ \mathrm{F} \mathrm{DB}, 69 \infty \mathrm{F}$ WB.

$24 \infty \mathrm{F}$.

$24 \infty \mathrm{F}$.

3012.

\subsection{Indoor Design Conditions}

Indoor summer and winter design conditions for the OAB HVAC systems are specified in Table 3-3.

\subsection{Ventilation}

Outside air make-up for ventilation shall be provided in accordance with the ASHRAE Standard 62 to provide at least $20 \mathrm{cfm} /$ person. Mechanical and electrical equipment spaces shall be ventilated to remove equipment heat loads and maintain air temperatures and pressurization specified in Table 3-3.

Provisions shall be made in the Assembly Area/Measurement and Alignment Room for the future installation of an open fume hood with exhuast fan and vent stack, approximately 2000-cfm capacity, for a sol-gel coating operation.

Provisions shall be made for automatic shutoff of the nitrogen supply system when the HVAC systems are not operating (see Section 3.2.1.8.3).

Restrooms shall be ventilated at $2 \mathrm{cfm} / \mathrm{sq} \mathrm{ft}$ or 12 air changes $/ \mathrm{hr}$, whichever is greater.

\subsection{Filtration}

The HVAC systems shall be designed to provide filtered, temperature- and humidity-controlled air to all parts of OAB. Systems indicated in Table 3-3 to provide clean room and clean zone environments shall incorporate appropriate HEPA and/or bag-type filters to achieve the specified conditions. Where used, HEPA filters shall be rated for a minimum of $99.99 \%$ efficiency for 0.3 -micron particles. 
HVAC equipment serving Class 100 clean rooms shall be designed for a minimum of $80 \%$ HEPA-filtered ceiling coverage with a minimum average airflow of $70 \mathrm{cfm} / \mathrm{sq} \mathrm{ft}$.

Table 3-3 - Indoor HVAC Design Conditions

\begin{tabular}{|c|c|c|c|}
\hline Building Space & $\begin{array}{c}\text { Temperature } \\
(\infty \mathrm{F})\end{array}$ & $\begin{array}{c}\text { Relative } \\
\text { Humidity } \\
(\%)\end{array}$ & $\begin{array}{r}\text { Pressure } \\
\text { (in. } \mathrm{H}_{2} \mathrm{O} \text { ) }\end{array}$ \\
\hline Class 100 Clean-Room Spaces: & & & \\
\hline Ass'y/Meas/Alignm't Rm & $68 \pm 0.5$ & $45 \pm 15$ & TBD \\
\hline Office/Computer Rm & $68 \pm 0.5$ & $45 \pm 15$ & TBD \\
\hline Gowning Rooms & $68 \pm 0.5$ & $45 \pm 15$ & TBD \\
\hline Class 1000 Clean-Room Spaces: & & & \\
\hline Mech Comp Clean'g Rm & $68 \pm 0.5$ & $45 \pm 15$ & TBD \\
\hline Transfer Facil to Corr Link & $68 \pm 0.5$ & $45 \pm 15$ & TBD \\
\hline Class 10,000 Clean-Room Spaces: & $68+05$ & $45+15$ & TBD \\
\hline Miechi halsiel hiea & & & \\
\hline Optics Transfer Area & $68 \pm 0.5$ & $45 \pm 15$ & TBD \\
\hline Clean Zones (Class 100,000): & & & \\
\hline Transfer Facil to Corridor & $68 \pm 0.5$ & $45 \pm 15$ & TBD \\
\hline Toilet Rooms & $68 \pm 0.5$ & N/A & TBD \\
\hline $\begin{array}{l}\text { Support Area Spaces: } \\
\text { Loading Area }\end{array}$ & $72 \pm 4$ & N/A & TBD \\
\hline Equipment Rooms & $100 \max / 50 \mathrm{~min}$ & N/A & N/A \\
\hline Mechanical Loft & N/A & N/A & N/A \\
\hline
\end{tabular}

HVAC equipment serving Class 1000 clean rooms shall be designed for a minimum of $30 \%$ HEPA-filtered ceiling coverage with a min. average airflow of $30 \mathrm{cfm} / \mathrm{sq} \mathrm{ft}$.

HVAC equipment serving Class 10000 clean rooms shall be designed for a minimum of $15 \%$ HEPA-filtered ceiling coverage with a minimum average airflow of a minimum of $15 \mathrm{cfm} / \mathrm{sq} \mathrm{ft}$.

The HVAC system for all clean rooms and clean zones shall consist of recirculating air fan-coil units having (minimum) four-row cooling coils, $30 \%$ filters, sound 
baffles, variable-frequency drives, double-wall construction, internal fan vibration isolation, and a minimum bearing life of $200,000-\mathrm{hr}, \mathrm{L}-10$.

Make-up air handling units shall be $100 \%$ outside air, with $30 \%$ and $95 \%$ filters, four-row heating coils, six-row cooling coils, six-row dehumidification coils, humidifier with DIW steam generator, sound traps, centrifugal fans, double-wall construction for outdoor application, spring isolators for internal fan isolation, and a minimum bearing life of $200,000-\mathrm{hr}, \mathrm{L}-10$

Maintenance provisions shall be included for servicing all HVAC equipment and changing out all filters.

\subsection{Pressurization}

Pressurization zones shall be established within the $O A B$ to maintain the specified cleanliness class and to make up required ventilation, exhaust air, and exfiltration.

\subsection{Noise and Vibration Control}

Rotating equipment shall be located in areas that are not vibration sensitive and/or shall be isolated from areas that are. All rotating equipment shall be installed on suitable vibration isolators to prevent the transfer of harmful vibrations to the operations spaces.

Noise criteria for occupied areas shall be NC 35 for typical conditioned spaces and NC 55 for clean rooms. Ambient vibration criteria shall not exceed the values in Table 3-1.

Air shall be distributed throughout the OAB HVAC systems at velocities that provide for sound attenuation and minimize noise and vibration.

The piping distribution system for hot- and chilled-water supply to coils in air handling units shall be configured to suppress hydraulic shock and minimize noise and vibration.

\subsection{Seismic Equipment Anchoring}

Rotating equipment shall be mounted within the building structure to resist seismic forces specified in SSDR 1.2.1, with appropriate vibration isolation and flexible duct connections to prevent building vibrations exceeding those specified in Table 3-1 (above). 


\subsection{HVAC Controls}

A direct digital control system shall be provided to regulate all functions of the OAB HVAC systems. The control system shall be connected to the LLNL site central monitoring system to indicate critical and important system failures.

\subsubsection{Plumbing}

Plumbing system designs for the OAB shall be performed in accordance with the Uniform Plumbing Code, LLNL Facility Standards, and applicable local codes.

Plumbing systems shall be provided as necessary to service the electric water heaters, sanitary fixtures, appliances and floor drains in the $O A B$, and to service drainage of stormwater from roof areas, foundations, and area drains.

\subsection{City Water}

Domestic cold water from the site underground city-water supply system, provided at approximately $100 \mathrm{psig}$, shall be reduced to $80 \mathrm{psi}$ at the building and sized in accordance with the required fixture units. Low-flow fixtures shall be used, and the system design shall comply with Americans with Disabilities Act requirements. In addition to serving sanitary fixtures, the system shall include a drinking fountain, electric water heater, and process water requirements (see Section 3.2.1.8.1).

\subsection{Sanitary Waste}

A sanitary soil/waste and vent system shall be provided and sized on the basis of the fixture requirements and a minimum flow velocity of $2 \mathrm{ft} / \mathrm{s}$, in accordance with LLNL Facility Standards and applicable local plumbing codes. Traps shall be provided with integral trap primers. The interior sanitary system shall be connected to the exterior underground sanitary sewer.

Four-inch, integral-trap floor drains shall be provided in the concrete floor slabs beneath the raised floor of the Mechanical Component Ceaning Room and Assembly Area to mitigate flooding from potential spills of deionized water. Traps shall be equipped with plugs to permit retention of water until it has been evaluated prior to disposal.

\subsection{Stormwater Drains}

A rainwater collection system shall be provided, consisting of roof scuppers, downspouts, area drains, foundation drains, and associated piping to convey the water away from the building. The number, size, and configuration of roof scuppers and downspouts shall be adequate to expedite removal of water and prevent flooding of the roof. The entire system shall be designed to accommodate the maximum design rainfall. 
Stormwater drain piping shall be provided to convey rainwater away from roof downspouts, foundation drains, and an area drain near the loading area. Piping shall be routed away from the building, sloped at $1 / 8$ in/ $\mathrm{ft}$ to the LLNL site storm drainage system. The system shall be designed in accordance with LLNL Facility Standards and applicable local codes.

\subsubsection{Fire Protection}

Fire suppression system designs for the $O A B$ shall be performed in accordance with the following standards:

- National Fire Protection Assn (NFPA) Standards.

- Factory Mutual (FM) Standards.

Fire suppression for $O A B$ spaces shall consist of automatic dry-pipe sprinkler systems and portable fire extinguishers. System design density shall be based on NFPA Ordinary Hazard, Group 2 occupancy. Sprinkler systems shall be designed and installed according to NFPA 13.

The sprinkler system water supplies shall be served by connection to the NIF site's water system loop to a riser in the mechanical room to prevent freezing. Service connections at the building shall include backflow prevention, flow detector alarms, valve supervision, Fire Department connections, inspector's tests, and drains. An exterior post-indicator valve shall be provided for building isolation.

\subsubsection{Material Handling}

Design of hoisting and lifting equipment for the $O A B$ shall be performed in accordance with applicable standards of the following organizations:

- American Gear Manufacturer's Association (AGMA).

- American Institure of Steel Construction (AISC).

- American National Standards Institute (ANSI).

- American Society for Testing and Materials (ASTM).

- American Society of Mechanical Engineers (ASME).

- American Welding Society (AWS).

- Anti-Friction Bearing Manufacturer's Association (AFBMA).

- Hoist Manufacturers Institute (HMI).

- Institute of Electrical and Electronics Engineers (IEEE).

- National Electrical Manufacturers Association (NEMA).

- National Elevator Industry, Inc. (NEII).

- National Fire Protection Association (NFPA).

- Underwriters Laboratory (UL). 
Two electrically operated lifts, each having a capacity of TBD, shall be provided for transferring components and assemblies from the OAB to the corridor link to the LTAB: one from the Mechanical Component Cleaning Room and one from the Assembly Area. The lift platform shall be at least TBD ft by TBD ft and shall have a vertical speed of TBD ft/min. The vertical travel of the lift shall be from the OAB raised floor level, sufficiently below that level to accommodate the lifting equipment and a TBD-ft-high payload.

Motors, gear boxes, bearings, and other components shall be sealed so that contamination of clean-room spaces by lubricants cannot occur. Sufficient access space shall be provided for maintenance of the lift equipment.

\subsubsection{Mechanical Process Piping Systems}

Mechanical process piping systems for operations use in the $O A B$, including deionized water (supply and return), compressed air, and vacuum cleaning, shall be designed and installed in accordance with applicable portions of the following standards:

- Uniform Plumbing Code, ICBO.

- Boiler and Pressure Vessel Code, ASME.

- LLNL Facility Standards.

\subsection{Deionized Water}

Water for operations use shall be provided from the city water supply system described in Section 3.2.1.5.1 to feed deionized water system equipment.

Deionized water (DIW) shall be provided by generating and polishing equipment located in the Mechanical Equipment Room, a 10,000-gal exterior storage tank, supply and return pumps, and distribution piping to TBD stations in the clean-room spaces of the building. The system shall be capable of providing and recycling a total of TBD gal/min of TBD quality water on a continuous (timing TBD) basis.

\subsection{Compressed Air}

Dry compressed air (TBD cfm) for conventional facilities instrumentation and pneumatic tools shall be provided throughout $O A B$ at 100 psig from the SEB (see SSDR 1.2.1). Distribution piping (capacity TBD) shall be routed to meet buildingrelated instrumentation and equipment requirements and supplied to isolation valves and capped stubs at TBD locations in the clean-room spaces (size, material, and flow rate TBD) for tools. 


\subsection{Nitrogen}

Nitrogen piping (only) shall be provided to TBD stations for cleaning optical and other components. Distribution piping (capacity TBD) shall be routed from an underground building penetration to isolation valves and capped stubs in all cleanroom spaces in the building.

The nitrogen supply piping shall be equipped with an automatic shutoff valve to isolate the system when the HVAC system is not operating and when there is an oxygen defieciency in the building atmosphere (see Section 3.2.1.9.5.4)

\subsection{Vacuum Cleaning (Housekeeping)}

A built-in industrial-grade vacuum system shall be provided for general housekeeping in the clean-room spaces of the OAB. The central unit shall be located in the Mechanical Equipment Room, with suction tubing routed in each clean room to self-closing outlet fittings with suitable lengths of hose, fittings, and nozzles spaced at 20 -ft centers around each room. The system shall have sufficient capacity to operate three stations simultaneously.

Process vacuum service, independent of OAB conventional facilities, is to be separately provided by the NIF Project.

\subsubsection{Electrical and Industrial Electronics}

Electrical systems designs for the LTAB shall be performed in accordance with the following standards:

- National Electrical Code, NFPA 70.

- Edison Electric Institute (EEI).

- Illuminating Engineering Society (IES) Lighting Handbook.

- Institute of Electrical and Electronic Engineers (IEEE).

- Insulated Cable Engineers Association (ICEA).

- National Electrical Manufacturers Association (NEMA).

- Underwriters Laboratories (UL).

- Lighning Protection Institute (LPI).

- National Fire Protection Association (NFPA).

- LLNL Facilities Standards.

All equipment, raceways, cable trays, fixtures, and devices shall be supported from the building structure to resist seismic forces specified in SSDR 1.2.1, with appropriate vibration isolation where necessary to prevent building vibrations exceeding those specified in Table 3-1. 


\subsection{Normal Power Distribution}

Electrical power feeders originating from a sectionalizing switch to an outdoor padmounted transformer shall supply a $480 / 277-\mathrm{V}$ power distribution center in the Electrical Equipment Room, which shall supply power to panelboards and motor control centers in the OAB.

Motor control centers shall be located in the mechanical loft space, away from vibration-sensitive areas. All motors $15 \mathrm{HP}$ and larger shall be provided with power-factor correction capacitors located near the motors.

Power distribution feeders shall be routed in the mechnical loft area whenever practical. Service drops for operations power and receptacles shall extend to panelboards located in return air chases, accessible from the clean-room spaces.

Dry-type transformers shall transform power from 480-V, 3-phase, to $208 / 120-\mathrm{V}, 3-$ phase, 4-wire, and shall supply power to $208 / 120-\mathrm{V}$ panelboards, which shall distribute 208/120-v power throughout the building, including receptacles. Each cleanroom area shall be provided with a $225 \mathrm{amp}, 208 / 120-\mathrm{V}, 3$-phase, 4-wire panelboard.

Panelboards and dry-type transformers shall meet the minimum requirements of LLNL Facilities Standard PEL-E-16470 and PEL-E-7/C.

A complete access-floor power-distribution/wire-management system shall be provided for clean rooms with raised floors. Conduits, outlets, and junction boxes in clean rooms shall be capable of being sealed. Rooms with concrete floors shall have receptacles installed on the perimeter walls. Ground fault protection shall be provided on circuits feeding water-spray cleaning units.

Standby power and uninterruptible power are not required for the OAB.

\subsection{Lighting}

Lighting levels shall be provided at illumination levels recommended by IES Standards. Lighting fixtures in clean-room areas shall be suitable for the clean room classification and suspended ceiling system in which they are installed. Fluorescent lighting fixtures shall use energy-efficient lamps and electronic ballasts. Microprocessor-based lighting relay cabinets shall be provided for automatic lighting control, with manual override capability.

Exterior lighting shall use HID fixtures and be provided with photocells. The outdoor fixtures shall have HPS-type lamps. 
Emergency lighting and exit signs in clean-room areas shall be provided by selfcontained, sealed lighting fixtures with battery/inverter units. Emergency lighting and exit signs for other areas shall be provided by self-contained, intergral battery/ inverter units. Exit signs shall be located above doors along all egress paths.

\subsection{Grounding}

A \#4/0 AWG soft-drawn bare copper (SDBC) grounding ring shall be provided around the perimeter of the building, with 3/4-in. by $10-\mathrm{ft}$ copper-clad ground rods spaced at 40 - $\mathrm{ft}$ ctrs along its length. An exposed ground grid of wires or bars shall be provided throughout the underfloor spaces of clean rooms with raised floors. Wallmounted, visible ground bars shall be provided in clean rooms with concrete floors. The ground grid, bars, and all building structural columns shall be bonded to the building grounding ring with exothermic welds or bolted ground clamps.

Grounding shall meet the guidelines of LLNL Facilities Standards PEL-E-16450 and the NIF Grounding Plan, L-17346, NIF-LLNL-94-211.

\subsection{Air Ionization}

An air ionization system shall be provided for the Class 100 clean-room space of the Assembly Area/Measurement and Alignment Room, to eliminate potential electrostatic discharge and particle contamination due to electrostatic attraction. The system shall consist of a controller and low-voltage emitters mounted in the suspended ceiling.

\subsection{Industrial Electronics}

\subsection{Telecommunications}

The telecommunications system design and installation for the $\mathrm{OAB}$ shall be performed in accordance with EIA/TIA-569 and EIA/TIA-568.

A telecommunications structure wiring system shall be provided to support standard telephone and data systems connections. Each system outlet shall include a coverplate and two modular connection jacks, two loop-grade, multimode optical fibers, one four-pair, Category III or better cable, and one four-pair, Category V cable in a raceway to a telecommunications closet in the Electrical Equipment Room. Punch-down blocks and power outlets shall be provided in the closet. 


\subsection{Fire Detection and Alarm}

Fire detection and alarm systems for the $O A B$ shall be designed and installed according to the requirements of NFPA 72 and NFPA 70. Designs shall incorporate "intelligent" detection and actuation devices monitored by signalling line circuits. A Fireman's Fan Shutdown Panel shall be interfaced with the HVAC control system to allow manual override control of fans and dampers during emergencies.

The building fire alarm control panel shall be slaved to the existing LLNL fire alarm system. The fire alarm system shall include connections to sprinkler-water flow and valve-tamper switches, manual pull stations at each building exit door, ceilingmounted area smoke detectors in all building areas and under raised floors (complete coverage), and duct-type smoke detectors in the air-handling ductwork. The system shall be in compliance with ADA requirements.

\subsection{Evacuation Voice Alarm}

Evacuation Voice Alarm (EV/A) system design and installation for the OAB shall conform to NFPA 72 requirements for an EV/A System, NFPA 70, and ADA. Wiring styles shall be determined according to NFPA 101, Life Safety Code.

The system shall be a new zone extension from the existing LLNL system. Speakers, strobes, and signal circuit wiring shall be provided to cover all areas of the building. The amplifier rack will be located in the telecommunications room of the Electrical Equipment Room.

The EV/A system shall energize the visual-alarm indicating appliances and drive the audible alarms. The EV/A system shall provide fire alarm annunciation, evacuation paging, and building paging.

\subsection{Oxygen Deficiency and Nitrogen Monitoring}

System(s) shall be provided in the operations spaces to monitor and alarm a deficiency of oxygen and the presence of excessive nitrogen. Sensors shall detect the existence of these conditions at TBD locations and shall activate audible and visual alarms locally, at the Office/Computer Room, and at a central LLNL dispatch station.

The sensors shall also cause automatic shutoff of the nitrogen supply system under these conditions.

\subsubsection{Verification of OAB Designs}

Refer to Section 4.0, Quality Assurance 


\subsection{Design and Construction}

\subsubsection{Civil}

Not applicable

\subsubsection{Structural}

TBD - to be described after design is established by drawings and specifications.

\subsubsection{Architectural}

TBD - to be described after design is established by drawings and specifications.

\subsubsection{Heating, Ventilating, and Air Conditioning}

TBD - to be described after design is established by drawings and specifications.

\subsubsection{Plumbing}

TBD - to be described after design is established by drawings and specifications.

\subsubsection{Fire Protection}

TBD - to be described after design is established by drawings and specifications.

\subsubsection{Material Handling}

TBD - to be described after design is established by drawings and specifications.

\subsubsection{Mechanical Process Piping}

TBD - to be described after design is established by drawings and specifications.

\subsubsection{Electrical \& Industrial Electronics}

TBD - to be described after design is established by drawings and specifications.

\subsection{Logistics}

TBD - to be described after CM has completed construction planning. 


\subsection{Quality Assurance Provisions}

The quality of the $\mathrm{OAB}$ and its subsystems is assured through the implementation of the NIF Project management system, which is described by procedural controls in the Project Control Manual and planning documents, such as the Quality Assurance Program Plan, Project Execution Plan, and Configuration Management Plan.

These controls address required performance of assurance measures, such as reviews, inspections, and assessments, to be included at every phase of work involved in the acquisition of the $\mathrm{OAB}$ and its subsystems, including the requirement that each major participant in the Project establish its own QA Program (management system) covering its work on the Project.

The following paragraphs address aspects of the NIF QA Program for the OAB and its subsystems.

\subsection{Q-Levels (Quality Assurance Levels)}

As part of the NIF QA Program provision to focus management attention commensurate with the importance of Project elements, all OAB subsystem and their components were analyzed according to NIF Procedure 1.6, Assignment of Q-Levels, to establish their relative importance to Project success. The results of these analyses are characterized by the Q-Levels (quality assurance levels) identified in the attached DRAFT Q-List, Table 4.1-1. There are three Q-Levels in descending importance from one to three.

Table 4.1-1 DRAFT Q-list: OAB

\begin{tabular}{|c|c|c|c|c|}
\hline \multirow{2}{*}{$\begin{array}{c}\text { WBS } \\
\text { element } \\
\text { number }\end{array}$} & \multirow[t]{2}{*}{ WBS element title } & \multicolumn{2}{|c|}{$\begin{array}{l}\text { Assigned } \\
\text { quality level }\end{array}$} & \multirow[t]{2}{*}{ Why not Q-Level 3? } \\
\hline & & 1 & 3 & \\
\hline 1.2 .2 & NIF Experimental buildings & & & \\
\hline 1.2 .2 .3 & Optics Assembly Building & & & \\
\hline 1.2 .2 .3 .1 & Optics assembly building - Area 1 & & & \\
\hline 1.2 .2 .3 .1 .1 & Structural & & & \\
\hline 1.2 .2 .3 .1 .1 .1 & Foundations & & $\mathbf{x}$ & \\
\hline 1.2 .2 .3 .1 .1 .2 & Steel Structures & & $\mathbf{x}$ & \\
\hline 1.2 .2 .3 .1 .2 & Mechanical & & & \\
\hline 1.2.2.3.1.2.1 & HVAC System & & $\mathbf{x}$ & \\
\hline & Exhaust fans & & $\bar{x}$ & \\
\hline & Primary Air Circulation Fans & & $\bar{x}$ & \\
\hline & Make-Up Air Fans & & $\bar{x}$ & \\
\hline & Chilled Water Control Valves & & $\bar{x}$ & \\
\hline & Local Digital Control System & & $\mathbf{x}$ & \\
\hline & Cooling/Heating Coils H215 & & $\bar{x}$ & \\
\hline
\end{tabular}




\begin{tabular}{|c|c|c|c|c|}
\hline & Filters & & $\bar{x}$ & \\
\hline 1.2 .2 .3 .1 .2 .2 & Plumbing & & $\bar{x}$ & \\
\hline 1.2.2.3.1.2.3 & Fire Protection & & & \\
\hline & Detectors & $\mathbf{x}$ & & $\begin{array}{l}\text { Failure or } \\
\text { malfunction may } \\
\text { result in fatali- }\end{array}$ \\
\hline & Fire control panel & $\bar{x}$ & & $\begin{array}{l}\text { ties and injuries in } \\
\text { case of fire. }\end{array}$ \\
\hline & Fire water valves & $\mathbf{x}$ & & \\
\hline & Fire protection equipmnet & $\mathbf{x}$ & & \\
\hline$\overline{1.2 .2 .3 .1 .2 .4}$ & Nitrogen Cooling System & & & \\
\hline & Programmable logic controller & & $\mathbf{x}$ & \\
\hline & Nitrogen handling unit & & $\bar{x}$ & \\
\hline & Nitrogen Vaporizer & & $\bar{x}$ & \\
\hline & Nitrogen storage tank & & $\bar{x}$ & \\
\hline & Instrumentation & $\bar{x}$ & & $\begin{array}{l}\text { Failure may result } \\
\text { in fatalities and } \\
\text { injuries }\end{array}$ \\
\hline 1.2.2.3.1.2.5 & Deionized water cooling system & & & \\
\hline & Programmable logic controller & & $\mathbf{x}$ & \\
\hline & Heat Exchanger & & $\bar{x}$ & \\
\hline & Pumps and piping & & $\bar{x}$ & \\
\hline & Instrumentation and conrol valves & & $\bar{x}$ & \\
\hline 1.2.2.3.1.2.6 & \begin{tabular}{|l|} 
Seismic Restraints \\
\end{tabular} & $\mathbf{x}$ & & $\begin{array}{l}\text { Failure may result } \\
\text { in fatalities and } \\
\text { injuries }\end{array}$ \\
\hline 1.2.2.3.1.2.7 & Mechanical Speciallities & & $\bar{x}$ & \\
\hline $1.2 .2 \cdot 3.1 .3$ & Electrical & & & \\
\hline 1.2 .2 .3 .1 .3 .1 & Main distribution system & & $\mathbf{x}$ & \\
\hline 1.2.2.3.1.3.2 & $\begin{array}{l}\text { Computers, diagnostics, and } \\
\text { instrumentation }\end{array}$ & & $\mathbf{x}$ & \\
\hline 1.2.2.3.1.3.3 & UPS & & $\mathbf{x}$ & \\
\hline 1.2 .2 .3 .1 .3 .4 & Grounding & $\bar{x}$ & & $\begin{array}{l}\text { Failure may result } \\
\text { in fatalities and } \\
\text { injuries }\end{array}$ \\
\hline 1.2.2.3.1.3.5 & Safety \& security system & $x$ & & $\begin{array}{l}\text { Failure may result } \\
\text { in fatalities and } \\
\text { injuries }\end{array}$ \\
\hline $1.2 .2 \cdot 3.1 .3 .6$ & Telecomminication and data transfe & & $\mathbf{x}$ & \\
\hline
\end{tabular}




\subsection{Quality Requirements}

The quality requirements for the $\mathrm{OAB}$ and its subsystems are specified in the applicable codes and standards cited in this SSDR, and, in relation to their Q-Levels, may have additional attributes identified in the specific requirements listed in Section 3.2.1, Performance and Physical Characteristics. These requirements may appear as system characteristics in OAB drawings and specifications to which the text refers in Section 3.1.1, System Description.

\subsection{Quality Assurance Measures}

\subsubsection{OAB Subsystems}

Construction specifications associated with each of the OAB subsystems shall contain provisions (such as inspections, documentation, certifications, and witnessed tests) for assuring that the specified quality is achieved and delivered to the NIF Project. Inspections, tests, and other QA provisions required by the codes and standards cited in the specifications shall be considered minimum requirements for $Q$ Level 3 components. Additional provisions for Q-Level 1 and 2 components in OAB subsystems shall be specifically identified in their specifications.

\subsubsection{Subsystem Design Verification}

Design verification is accomplished through implementation of Project-approved Architect-Engineer (AE) design control procedures of the AE's QA Program, including review of all calculations, analyses, studies, drawings, and specifications produced by the $\mathrm{AE}$, and all shop, fabrication, and erection drawings generated by suppliers and installers during construction. Verification of AE implementation of its QA Program is performed by NIF Project staff members in accordance with NIF Procedures 5.1, Design Review, and 10.1, Independent Assessments, of the NIF Project Control Manual (QA Program).

\subsubsection{Subsystem Construction Verification}

Construction verification is accomplished through implementation of Projectapproved Construction Manager (CM) inspection procedures of the CM's QA Program. Verification of CM QA Program implementation and further verification of the fabrication, installation, and construction activity is performed by NIF Project staff members in accordance with NIF Procedures 7.3, Vendor Surveillance, and 10.1, Independent Assessments, of the NIF Project Control Manual (QA Program). 


\subsection{Notes}

(Blank)

\subsection{Revision Record}

Rev.

letter

A

Date

$3 / 25 / 96$

B

$8 / 145 / 96$
Changed by

Kempel

Kempel/Knawa

\section{Description}

Complete reformat and rewrite of existing information. Lower-tier requirements moved to SSDRs. All requirements reassessed and updated, based on CDR and ACD information; flowdown tracking and verification methods established.

Complete reformat and rewrite of existing information. Generic requirements moved to Site Improvements SSDR. All requirements reassessed and updated, based on mid-Title I Development information. 


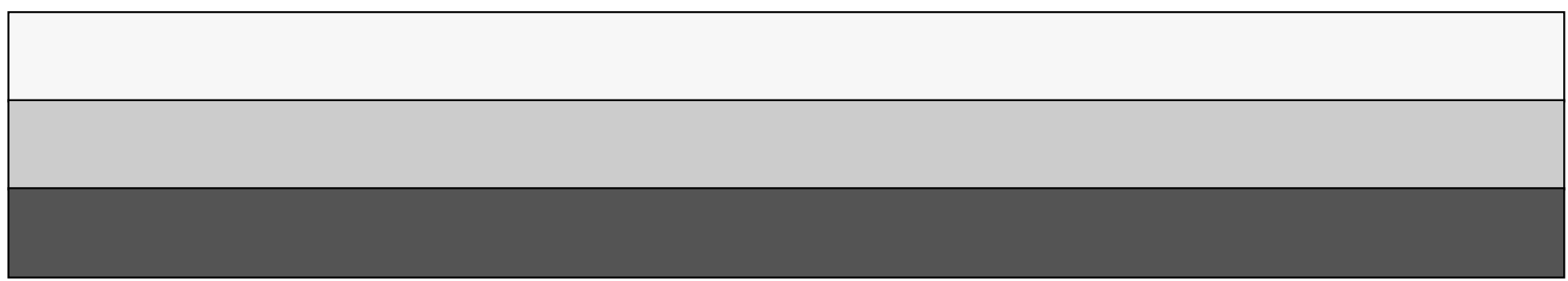

